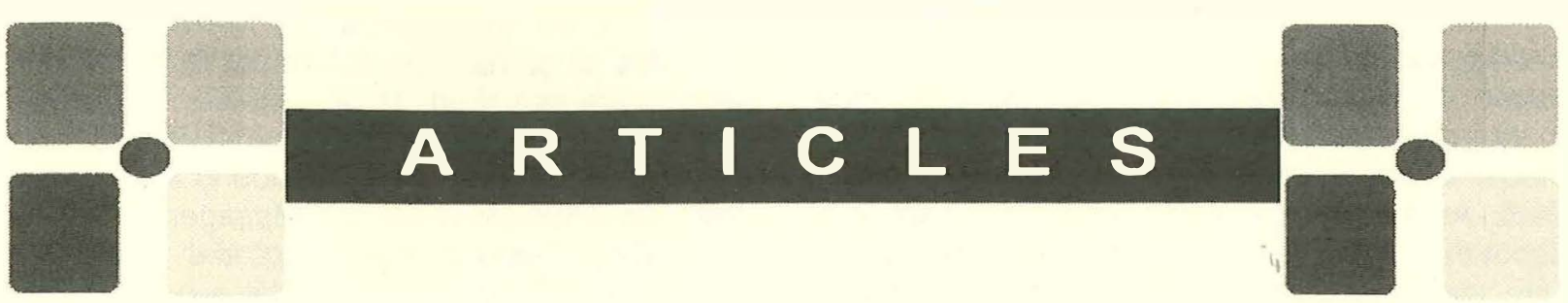

\title{
Leadership of Academic Libraries: A Literature Review
}

\author{
By Sharon Gray Weiner
}

Vanderbilt University

\begin{abstract}
This review synthesizes what is known about the characteristics and leadership style of university librarians and academic library directors. It is the leadership of the library that determines whether a philosophy and vision are articulated and to what extent they are implemented. Leadership influences a library's effectiveness, institutional role, and adaptability. Publications on recruitment, leadership potential identification, career development, roles and responsibilities, and characteristics and management style were included.
\end{abstract}

\section{Introduction}

The purpose of this review is to synthesize what is now known about the characteristics and leadership style of university librarians and academic library directors. Each of the 2487 four-year postsecondary institutions in the United States ("Almanac," 2003; 2) either have their own libraries or provide library services through an outside institution. The philosophy, mission, and functions of these libraries strongly influence access to information resources and related services critical to teaching and research. They affect the ability of the students and faculty to identify and effectively search for the most relevant information for their needs. It is the leadership of the library that determines whether a philosophy and vision are articulated and to what extent they are implemented. Leadership affects a library's effectiveness, its role in the academic institution, and its adaptability to new functions and initiatives.

The academic library has been greatly affected by rapid and discontinuous changes in its professional environment. Those changes include: dramatic increases in the cost of materials while budgets decreased; new digital formats and communication technologies; improvements in information availability; growth of interdisciplinary research; issues with the commercial scholarly publishing industry; and expectations that the library will secure some funding through development and grants. (Travica, 1999; 181) (Renaud \& Murray, 2003; 164) (Winston \& Dunkley, 2002) Other trends are: increasing turbulence; an information-based, service-oriented society; patron expectation of high quality library services; stakeholder expectation of shared responsibility with the library; more complex organizations; and the need for a proactive approach. (Jurow, 1990; 62) Libraries are at a critical juncture due to new demands in information technology, the increase in the number of distance education programs, new models of support for research and teaching, and a declining resource base. These factors "have forced the significant questioning of longstanding principles and practices throughout library services and operations," so the ability to anticipate and manage change is critical. (Martin, 1997; 49) Even more, it is necessary to undergo a "fundamental rethinking and redesign of library roles, services, and operations in universities which are also undergoing great change." (Ferguson \& Metz, 2003; 96)

Internal organizational structures of libraries are different from in the past. This is very likely a result of occurrences in the external environment. Hierarchies are flattened, middle management has been reduced, departments are becoming integrated, and new functions have been incorporated. 
(Travica, 1999; 181) Greater accountability is expected, and there is increased competition. Teambased decision-making and participative management are common, and the "learning organization" model is being introduced. (Winston \& Dunkley, 2002) As a result, there has been much discussion about the role of the library and about what leadership characteristics will successfully transform, propel, or at the very least, sustain the academic library. "Few professions can be said to have spent as much time contemplating its present and future role as have academic librarians." (Renaud \& Murray, 2003; 164)

Another perspective was shown as a result of a survey of directors of large libraries. (Cottam, $1994 ; 17)$ It was conducted to contrast roles and responsibilities in 1994 as compared with the previous five and ten year periods. The findings showed that there had been change, but there was not a consistent pattern of change among the respondents. Traditional managerial roles were prevalent and much of the work was similar to what was done in the past, but there was a new emphasis on fundraising. Directors continued to be involved with cooperative projects, to collaborate with computer personnel, to submit grant proposals, to incorporate Total Quality Management, and to engage in globalization initiatives. In contrast, a 1999 survey of library directors showed that their organizational priorities were to focus on quality of services, to train patrons in search techniques, to provide materials in any format, to encourage employee innovativeness, and to develop electronic delivery tools along with the print collection. (Travica, 1999; 190)

This review of the literature on academic library leadership in the United States includes published research studies, theories and models, literature reviews, books, and journal articles published between 1980 and 2003. Omitted are editorials, conference proceedings, and opinion pieces as well as information about two-year colleges or specialized academic libraries, such as law and medical. Citations were identified by exhaustive searches of the ERIC, Education Abstracts FullText, Library Literature, General BusinessFile ASAP, Ps yclnfo, Digital Dissertations, and WorldCat databases. Relevant concepts included: leader characteristics, leadership methods and strategies, vision, innovation, influence, mentoring, organizational outcomes, management style, effectiveness, power, persuasion, job satisfaction, and career paths. Bibliographies of those resources were examined to garner additional references. Key authors were identified and searches for their works were performed. Websites of primary publishers of library science books were searched. This introduction is followed by sections on: Recruitment, Leadership Potential, and Career Development; Roles and Responsibilities; and Characteristics and Management Styles. Table One shows that most of the publications cited were surveys.

\section{Recruitment, Leadership Potential, Career De- velopment}

"Leadership of tomorrow's academic libraries is not for the faint of heart." (Matthews, 2002) There is concern that there is a shortage of librarians capable of providing effective leadership during these turbulent times. (Renaud \& Murray, 2003; 164) One study of academic librarians revealed that they tended to score lower than normative groups on managerial talent. "It would appear that academic librarians, no matter by what route they come to the field, tend to fit a certain personality profile and that, when it comes to managerial talent, they are generally not as able as people in other occupations." (Moore, 1981)

\section{Potential Leaders}

What characteristics should aspiring library directors need to have or develop? One library school dean looked for knowledge, ambition, common sense, and character in student leaders. (Wedgeworth, 1989; 41-2) Potential leaders should be innovative and creative risk takers; flexible; have the cognitive ability to deal with complex scenarios; have effective skills in dealing with people; have technical expertise; and be willing to learn. (Martin, 1997; 57) In an organization that has a flat hierarchy, leadership opportunities can "occur at all levels of the organization since authority is dispersed and layers of management and supervision have been reduced... university libraries with flat organizations might be more successful than those with hierarchical structures in producing future leaders, since they expose a broader range of librarians and staff to managerial challenges." (Renaud \& Murray, 2003; 170-173)

A study of characteristics of potential leaders was conducted by comparing a selective group of academic library managers in the UCLA Senior Fellows Program with a randomly-sampled control group of members of the Association of College and Research Libraries. The study showed that the Senior Fellows were more than twice as visible, nearly twice as mobile, and three times more likely to assume management and leadership positions 
in comparison with the control group. The Fellows achieved all educational degrees and professional positions at younger ages; they had higher degrees, more publications, and greater organizational activity. (Anderson, 1985; 331)

A survey of directors of the Council on State University Libraries found a trend toward women obtaining director positions as external candidates and men obtaining positions through internal promotion. (Hatcher, 1997; 42) Hammond addressed the delicate issues related to being a successful internal candidate for a library leadership position. The person hired internally has the advantages of knowing the organization, the challenges, the budget, politics, and key people. But relationships with some people in the organization may become awkward. Those who are hired internally must convey their new role immediately and consistently. They can negotiate support from those who did not agree with the search committee's choice and channel the dissatisfaction into activities that will use strengths and best serve the organization. (Hammond, 2003; 188-9)

\section{Trends}

In 1994, Rooks analyzed trends identified from a classic 1973 study of decreasing lengths of tenure for academic library directors. Some of the trends in society and higher education discovered in the original study were growth of enrollment, changes in the college presidency, changes in education and research, the information explosion, economics, planning and budgeting, technology, changing management theories, unionization, and increasing control by state boards. The 1994 study added to the list lifestyle changes and ethnic and gender influences. The position of director for a major research library has become more demanding. The 1973 study identified three major qualities required of a director: flexibility, adaptability, and a willingness to accept change as a way of life; a stable temperament and the ability to maintain an emotional balance under constant tensions; and endurance. In 1994, "certainly these qualities have only increased in value." (Rooks, 1994) There was concern about whether excellent librarians would continue to be interested in director positions because of the inherent difficulties. Similar to academic deans and provosts, term appointments for library directors or institutional appointment options could be considered so library directors could return to a position within the library once their administrative appointment ended.
In a liberal arts college, there is a strong relationship between the individual and the college community. (Clemmer, 1997; 75) Directors of liberal arts college libraries who had worked previously in research institutions had high expectations of the colleges. They "anticipated relief from the management difficulties of large institutions, an intimate work environment in which one can deal with the major players on a face to face basis, and more involvement in the teaching learning process, including closer contact with faculty and students." (Clemmer, 1997; 78) The directors found that it was possible for them to make an impact on the entire institution and it was easier to accomplish things than in a research university. "In the smaller community, the players attribute a higher level of competence to each other based on familiarity and are less likely to depend on an institutional imprimatur." (Clemmer, 1997; 79) Directors had easy access to decision-makers and turf battles were almost non-existent. "Directing the liberal arts college library can provide much personal satisfaction." (Clemmer, 1997; 86)

It is not clear from the literature whether a second master's degree or doctorate is necessary for those who aspire to a director position. A survey of liberal arts college library directors showed that $\mathbf{4 0}$ percent of the directors had second master's degrees and 20 percent had doctorates. The author believed that degrees "cannot replace administrative aptitude, creativity, and knowledge in a successful college or university library director." (McCracken, 2000) However, some library directors advised those they mentor to pursue a Ph.D. (McNeer, 1988; 31) Williams believed that library directors who do not have a doctorate are at a disadvantage, but that more important than degrees is a program that is "interesting, dynamic, innovative, and especially responsive to the needs of the library's clientele." (D. E. Williams, 1998; 51)

The research literature is a valuable decisionmaking tool for leaders and can influence the thinking and behavior of a group. Understanding research methods and statistical analysis is key to informed decision-making and organizational success. (J. F. Williams \& Winston, 2003; 401) Library administrators are actively publishing research studies: sixteen per cent of the first authors of research studies in the five library journals that have the highest impact factor were academic library administrators. Seventy-seven per cent of the research studies published in College and Research Libraries were written by academic library administrators. (J. F. Williams \& Winston, 2003; 398-9) 
Nicholson and West Model

The Nicholson and West model of transition cycles can be applied to the process of becoming a chief librarian in an academic institution. "Preparation" is the first stage during which the aspirant prepares psychologically; assesses personal competence, and values; engages in professional development; actively networks; and gathers information about institutions and trends. The second stage is the "encounter" stage, which encompasses the time from the job interview to the first few weeks of employment. Success in the next stage, "adjustment," involves integrating informal socialization and already-developed skills with newly-acquired knowledge of the organization. A mark of the "stabilization" stage is the development of a constructive relationship with the supervisor: "true leadership, achievement, and work performance will be achieved and assessed." (Matthews, 2002)

\section{Learning Leadership}

One can learn informally about leadership by learning on the job, by taking every opportunity to learn and to grow, by developing an understanding of the academic community, by knowing who are the leaders and who are the followers, and by associating with leaders and learning from them. A leader should become adept at public speaking and written communication and be able to work with groups and to build consensus. Leaders need to be decisive and to understand the politics, purpose, and history of the institution. (Riggs \& Sabine, 1988; 114-6) One should find employment in a library that has a sense of excitement, is likely to stretch one's abilities, has a sense of community or unity of purpose, and employs people who are interested in their work and dedicated to doing it well. (Riggs \& Sabine, 1988; 121) People skills are essential because "if you're not effective in handling people, you won't be effective in handling the operation." (Riggs \& Sabine, 1988; 103)

Librarians can develop their visionary ability by working on projects that involve organizational analysis and abstract thinking. (Jurow, 1990; 67) It is difficult to learn how to inspire others, but knowing the ideas and ideals held in common by a group is an important beginning. A visionary message must be repeated in different ways to different groups. Examples should be credible, vivid, positive, and passionate. Leaders related that the best ways to develop self-confidence were to take courses and to participate in projects and task forces. (Jurow, 1990; 68, 7.0)
Development and fund raising are increasingly important in the job responsibilities of senior library administrators. Obtaining these skills can be challenging. "Although academic librarians are likely to develop expertise in some areas that appear to be important with regard to development responsibilities, such as managing staff and written, oral, and interpersonal communication, issues such as cultivation of relationships with donors and previous development experience are not likely to be part of the responsibilities of those librarians progressing through the professional ranks." (Winston \& Dunkley, 2002)

\section{Mentoring}

Leaders must actively develop successors. Extensive mentoring should take place and participation in professional development activities should be encouraged. (Renaud \& Murray, 2003; 170) Mentoring means "identifying talented new individuals and attracting them into an ever-changing and expanding profession, helping those with traditional credentials and experience to develop the qualities necessary for success in an environment of ambiguity, and providing productive learning experiences that build on existing strengths and minimize weaknesses." (Battin, 1998; 274) Mentoring also means surrounding oneself with the most intelligent colleagues, urging others to develop their potential, delegating and being available to work through problems together, selecting opportunities for individuals that require them to stretch, building on strengths and improving the weaknesses, and encouraging the development of new abilities. (Battin, 1998; 276) Mentoring was identified as the single most significant factor in the career advancement of women academic library directors. (Kirkland, 1997; 382) McNeer suggested that good supervision at the beginning of a career is a form of mentoring. Highly placed mentors can provide entrée to restricted forums. (McNeer, 1988; 27-28)

Negative experiences can be analyzed to serve as examples of how something could have been done better. Mentors look for leadership potential when screening mentees: energetic, capable librarians who are willing to grow into positions of responsibility; self-directed, imaginative people with a sense of humor, analytical skills, interpersonal ability, and the fortitude to make difficult decisions. Administrators advised mentees to look for new challenges, assume tasks that would highlight their competence, gain skills in working with groups, publish, and be involved in professional organizations. "Mentoring will occur more often in open library organizations where responsibilities are 
delegated, management is participatory and staff committees work on problems." (McNeer, 1988; 31)

Library leaders can use a variety of strategies to create a climate that encourages leadership development in their organizations. Some of those are: the use of task forces and committees; coordinator positions; promotion and reward systems; the organizational design itself (matrix models, flat hierarchies, quality circles); projects, "acting" positions, job rotations, internships, formal staff development programs, and the strategic planning process. (lannuzzi, 1992; 22-7)

\section{Roles and Responsibilities}

The following roles and responsibilities of academic library leaders have been discussed in the literature: garnering financial resources, strategic planning, perceptions of leader and library effectiveness, functions and challenges of the leader, and knowledge of organizational culture. Library leaders need to formulate goals and objectives for the library and then create a construct, or a mental image, of what their libraries should become. The vision should accurately reflect the current situation and clearly articulate a future direction. The leader needs to translate this vision into reality and communicate it to the library and the university frequently and consistently. (Riggs, 1998; 60) (Clemmer, 1997) (Gertzog, 1989b; 32) To be effective, a leader must be inspirational. They should try new organizational models. Risk-taking and experimentation should be encouraged. Libraries need leaders who can succeed within a global arena. They need to develop partnerships and coalitions to support their services while maintaining a secure infrastructure for operations. (lannuzzi, 1992; 20-1)

\section{Budget}

Obtaining and allocating financial resources is a key role of a library director. A 1987 study found that library directors understood budget allocation processes at their institutions, but were not as involved in planning and budgetary decision-making as they perceived they should have been. Those who were successful in obtaining institutional support for projects did so by stressing the importance of the library to the advancement of the institution as a whole. (Hyatt \& Santiago, 1987; 9) Talbot proposes changes to the budgeting process. "If libraries are to continue to be a vital part of the academic enterprise... Librarians must begin to see the budget for what it really is-the fiscal reflection of institutional intent...It is no longer sufficient to regard the budget merely as a source of funds; it is a tool for implementation and decision." (Talbot, 1982; 35)

\section{Strategic Planning}

Development of a long range plan is a responsibility of the director with the participation of the president and academic vice president. The plan should take the university's mission into account; have a strategy for collection development; include plans for technology and bibliographic instruction; address facility changes; collaboration with other institutions; special collections; and a development program. (Adamany, 1985; 8-11)

During the strategic planning process, a dynamic leader will ensure that the library's strategies are magnetic and adhesive. The director should involve staff in the process, provide motivation, mediate conflicts, and ensure an orderly integration of change. (Riggs, 1998; 59) "The big challenge facing us is how much of the traditional practices of academic libraries can be discontinued in order to bring forth a new way of doing things." (Riggs, 1998 ; 61) Directors must be self-motivated, credible, and results-oriented. Subordinates must be loyal and supportive; they should have pride and a sense of accomplishment; they should feel that they are an important part of a worthwhile endeavor. "The relationship between leaders and followers has to be one of strong, effective interdependence." (Riggs, 1998; 62-3) With the changes that are anticipated in libraries and technology, creativity and innovation will become common and the library will become a learning organization. (Riggs, 1998; 61-4)

\section{Director's Effectiveness}

The perceived effectiveness of the library director and of the library are closely connected. (J. R. Euster, 1986; 172) Whether a president commits adequate resources to the library is determined primarily by "whether the president has confidence in the library leadership, whether the library's plan is being carried out with demonstrable results, and whether the library reallocates substantially to meet internal change even when the library as a whole is in a steady state." (Adamany, 1985; 10) The college president's evaluation should be based on the library's strategic plan which would include measures and methods for evaluating library performance. "Many fine institutions with highly productive faculties have relatively undistinguished library operations. If the library cannot serve faculty needs as effectively as it should, the 
diversion of funds... may be better than putting still more money into a mediocre, but entrenched, library management staff." (Adamany, 1985; 17-9)

Kazlauskas' study of the relationship between leadership practices and employee job satisfaction determined that autonomy at work affected the job satisfaction of librarians more than leadership practices. Associate university librarians were less satisfied with their jobs than other academic librarians. Her premise was that library leaders were responsible for employee job satisfaction. (Kazlauskas, 1993; x, xi, 7, 8)

\section{Functions}

Chief academic officers and library directors were surveyed about the roles and responsibilities of the library, its organizational structure, and inclusion in governance, and fundraising and development roles. Perceptions of the future of the library differed among library directors themselves and between directors and chief academic officers. Directors believed it was important to be proactive but had not developed strategies to accomplish this. They preferred a team-based organizational model. Directors wanted to be included in strategic institutional planning but administrators did not perceive this as important. (Deekle \& De Klerk, 1992; 73)

A number of authors have suggested that directors must focus their energy and activities both on internal library operations and on external activities. They also should experiment with new management techniques. (Cargill \& Webb, 1988; 60) (Deekle \& De Klerk, 1992; 73) (Clemmer, 1997) (J. R. Euster, 1987)

Library directors did not agree on whether a traditionally structured or a functionally integrated approach to library organization is better. (Buttlar \& Garcha, 1992; 15) They thought the best reasons to reorganize staff were economics and to provide a more client-centered library. Their conclusion is that there is not one single organizational model that is best for all libraries. (Buttlar \& Garcha, 1992; 16) "Library leadership is situational. The success of a library leader is contingent on many factors, including skills that match the library's needs at a particular time." (Riggs, 1998; 56-7) To succeed, library directors must "recognize that different stages in the organization's life cycle will require different emphases; accept the idea that the same person may not be the appropriate leader for all organizational circumstances." (J. R. Euster, 1987; 109)

\section{Challenges}

In 2002, a study examined challenges that were perceived by academic library directors and by their supervisors. Both ranked user satisfaction and serials as the greatest challenges. Younger and newer directors perceived that organizational change, crime in the library, and training were also challenges. (McElrath, 2002)

Due to changes in information technology the "Iibrary director must be both an active and an effective advocate for the library on campus and a full participant in the life of the academic community. Librarians must participate in planning for the use of electronic technologies on campus, work collaboratively with computer professionals and others on campus, retrain staff, secure funding for both infrastructure development and operations, understand intellectual property issues, and learn to work in an environment in which change is a constant... The library director is responsible for making the case for this level of participation on campus in the face of administrators who believe that others more effectively represent the future." (D. E. Williams, 1998; 42) To alter the impression that it is not important to involve the library or that the library does not have anything to contribute takes "dues-paying, thick-skinned advocacy and general tenacity designed to portray the library organization as a savvy participant in campus decision making that understands the campus, the traditions of scholarship it pursues, and the technologies required to sustain and advance it." (D. E. Williams, 1998; 43)

Directors must integrate the library into the teaching and research efforts of the university. They must ensure that the library is associated with things that are valued by the institution. (D. E. Williams, 1998; 48) "To make this association, the library director must assume the role of change agent within the university and must transform the library into an organization that facilitates institutional change while maintaining its bridges to the traditions of the academy... Directors must present the library as a place that is both facile at dealing with the politics of the campus and above the kind of divisions that take place between colleges and departments." (D. E. Williams, 1998; 48)

\section{Organizational Culture}

Understanding organizational culture is crucial to effective leadership. (lannuzzi, 1992; 92) The elements of a library's culture include organizational values, management styles, norms, patterns of communication, and philosophy of service. The 
degree to which staff share in these elements determines the library's cultural maturity. (lannuzzi, 1992; 31)

Leadership of a tribal college library is an example of a different situational structure. The authors of a survey of library directors and staff in tribal college libraries focused on attitudes of tribal college staff about their work. More library directors than nondirectors said that ties to a tribal community or tribal college affected their employment decisionmaking. They saw their jobs as a means to a career goal and as an opportunity for personal growth. Pragmatic factors such as salary, benefits, and location were equally important to both groups. The directors "noted that the reality of their job fell short of their expectations... because of the unexpected range of job responsibilities, financial and infrastructure constraints, and the negative influence of tribal politics and college administrators." However, they believed that the remote locations, non-competitive salary, and low benefits were offset by the chance to help others, a strong sense of purpose, and the opportunity to become a more well-rounded individual. (Dilevko \& Gottlieb, 2002; 306)

\section{Characteristics and Management Style}

Power, diversity issues, leaders as change agents, and management styles are characteristics that influence the effectiveness of academic library leaders. The research literature suggests a consensus about effective leadership styles. The most effective ones are those that combine boldness, informed risk-taking, widespread consultation, and consensus-building. They are good listeners, are accessible to staff, have strong public speaking skills, and are consistent and self-confident. (Sheldon, 1992; 394-400) Leaders need "acute powers of analysis, abundant common sense, vibrant creativity, reasoned judgment, and a passionate commitment to the mission and goals of the extended higher education community." (Battin, 1998)

Hernon et al., reported the result of a recent Delphi study. These are the attributes that Association of Research Libraries directors should be adept at:

- Managing-maintains a productive work environment, is results-oriented and commited to service

- Leading-can function in a political environment, can manage and shape change, builds a shared vision, builds relationships, thinks "out- side the box," advocates for the library, engages in fundraising and donor relations

- Planning-sets priorities

- Dealing with others-has credibility with faculty and administration, is even-handed and selfconfident

- Personal traits-is comfortable with ambiguity, committed to job and profession, handles stress, is honest, energetic, intelligent

- Individual leadership traits-has good judgment, is innovative, articulates direction for library, is enthusiastic

The director should play an extensive role outside the library, serve as a change agent when necessary, and rely on a team for internal management. (Hernon, Powell, \& Young, 2002) (Hernon, Powell, \& Young, 2001)

Jurow identifies five leadership characteristics: vision, communication, trust, risk, and empowerment. (Jurow, 1990; 59) The knowledge and skills that leaders need are: ability to make choices and focus energy; understanding of group dynamics and strong interpersonal skills; willingness to take risks; ability to make a commitment to a course of action and focus the organization on accomplishing that goal; understanding of what motivates individuals and groups; and can build on the strengths of others. (Jurow, 1990; 63)

Wedgeworth states in a panel presentation on leadership that knowledge is a characteristic that is usually rated low but that a certain level of knowledge and understanding is assumed in a leadership position. It is a working tool necessary to exert leadership. (Wed geworth, 1989; 37) A director's authority should be predicated on knowledge. (Riggs \& Sabine, 1988; 109-10) (Gertzog, 1989b; 32) (Cargill \& Webb, 1988; 62) Euster reviewed the leadership and management literature in 1984 stating that there had been no comprehensive investigation of the characteristics of library leaders. She stated that successful library directors must "recognize that different stages in the organization's life cycle will require different emphases; accept the idea that the same person may not be the appropriate leader for all organizational circumstances; and utilize the dual concept of management and leadership as essential and related functions." (J. R. Euster, 1984) Leaders need to establish credibility with colleagues. A leader needs to listen, make the best judgment, and build consensus. (Riggs \& Sabine, 1988; 109-10)

Wiegand reported the reasons why academic library leaders were selected for a biographical 
handbook: unrecognized accomplishments; belief in the role of research libraries as promoting civic virtue; scholar-librarian; leadership of professional organizations; championing intellectual freedom and faculty status for librarians; expert on library buildings; improvement of a library system; influential publications; focus on intellectual aspects of librarianship; management innovations; and developer of library surveys. (Wiegand, 1983; 3-7) Euster's Two-Environment Model relates the leader to the internal and external environment of the organization. The model shows the library leader as the intermediary between the control environment (administrators, boards, legislatures) and the user environment (faculty, students). The directors expended the greatest effort in entrepreneur activities. Changes in facilities and in the internal organizational structure were associated with high activity of the leaders. There was only a moderate association between longevity of the director and amount of change in the organization. (J. R. Euster, 1989)

A study of the academic library director in an environmental context showed that colleagues outside the library tended to evaluate directors more highly than did internal subordinates. The leadership types that emerged were: The Energizer (high levels of activity and change, high reputation level); The Sustainer (high reputation, highly active, little organizational change); The Politician (low leader activity, low organizational change, effective reputation); The Retiree (inactive as a leader; organization is unchanging; not highly regarded or disregarded by colleagues). (Joanne Reed Euster, 1986 ; 146) Evaluation of these profiles indicates that there is no single characteristic or combination of characteristics that relate to effectiveness; rather, successful leader behavior is related to the organizational environment.

Characteristics of library directors of doctoral and comprehensive institutions differed from those of directors of smaller baccalaureate college libraries. Doctoral institution directors spend less time on internal roles; baccalaureate institution directors spend more time with faculty and students and see technical skills as important to their jobs. (Mech, 1990; 425)

Library leaders interviewed for a book opined that leadership is not based on personal characteristics. "Those persons who tend to do well in our field are able to get their work done through others and are able to keep focused on specific objectives and not get lost in the most current fad or the most popular direction. They are the ones who are willing to ignore conventional wisdom in terms of looking at a problem and trying to strike out in a different direction." (Riggs \& Sabine, 1988; 101)

\section{Power}

Power over setting objectives and policy, leadership style, role clarity, and expertise are significantly related to directors' perceived power. (Holmes, 1983) Subordinates' ideas about what makes a library director powerful differ from that of the directors and their superiors. They place as much emphasis on the importance of objectives and policy-setting as those of the other groups, but they also emphasize operations instead of strategy and budget. (Holmes, 1983; 158) The powerful director is seen "as a professional peer of senior status, a staff specialist with managerial duties." (Holmes, 1983; 155) A survey of power relationships in academic libraries showed no relationship between administrators' preferred power use, empowerment, and characteristics of the administrators. Their preference was to use "expert" power, then "legitimate" and "information" power. (Evans, 1997; 87) However, library leadership characteristics identified in a study by Gertzog did not mention power. (Gertzog, 1989b; 32)

Holmes' dissertation on the perceived power of academic library directors suggested that directors' power over strategic decision areas contribute most highly to perceptions of their overall power. Expertise also contributes significantly to perceptions of the directors' power. (Holmes, 1983) "Persons leading through position authority and personal power have a high potential of being effective directors." (Cargill \& Webb, 1988; 61) Position power is strengthened when leaders handle critical situations in a rational manner.

Gertzog examined leader backgrounds and careers to determine what social resources and professional activities were necessary conditions of leadership. Respondents most frequently selected leaders for their contribution of ideas and for their institutional affiliations; least often for their innovations and personal characteristics. Perceived leaders participated actively in professional associations, published frequently in the professional press, and held high organizational positions. (Gertzog, 1989a; ii) Matthews states that directors must be able to deal with ambiguity and function effectively when the rules and boundaries are not clear. "Adjustment is a continual process in dynamic organizations." (Matthews, 2002) 


\section{Diversity Issues}

Fisher questioned whether males actually dominate the administrative ranks of libraries. His study of library directory entries showed that males had administrative positions in 64 percent of large academic libraries and 58 percent of medium-large academic libraries. (Fisher, 1997; 234) A 1991 study showed that the percentage of female Association of Research Library directors had grown from a few in the 1970s to almost 30 percent in the late 1980s. (Myers \& Kaufman, 1991; 252) However, Mobley states that "there seems to be some substance to the criticism that the current model of leadership is only relevant to white males." Women are missing from discussions about personality traits in leadership and there is very little about minorities. (Mobley, 1989; 44)

A study of contemporary feminist theories in relation to career paths, work styles, and leadership practices of feminist librarians examined the effects of feminism on their careers and personal lives, the influence of other women, and the concepts and practices of feminist librarians who had leadership positions. The results showed that their feminism influenced their work as well as personal lives and that feminist librarians have contributed to new approaches to library work and leadership styles. (Freedman, 1984)

\section{Change Agents}

Hall studied the relationships between educational achievement, professional involvement and change agent characteristics of selected academic librarians. The characteristics were: educational attainment and continuing education activities, participation in on-campus activities, professional organizations, publishing activities, and research activities. Results showed that educational achievement was not significantly related to change agent characteristics; professional status was related significantly to two of the four measures. On-campus activities and research activities were the best predictors of change advocacy and leadership skills. (Hall, 1984)

Ability to influence is crucial because "there are very few power opportunities in our field." (Riggs \& Sabine, 1988; 101) The political position is one in which "decision-making is open to challenge by other parties wielding equal or greater influence, and where formal authority in library decisionmaking is liable to be usurped by other offices." (Holmes, 1983; 155) Since expertise was a predictor of directors' power, the director's power is influential rather than authoritarian. (Holmes, 1983;
155) Future investigation of academic library directors' power should incorporate a political model that would explore the library director's coalitions within the academic community and determine the nature of the influence. (Holmes, 1983; 156) Influence can be developed through continuity, reliability, and understanding what other people want. "It's a matter of developing extensive relationships, being able to work effectively with committees, but at the same time, being able to assert initiative and to state an unpopular position and back it up." (Riggs \& Sabine, 1988; 101-2)

Directors must be sensitive to their larger environment and adjust when it changes. They must "educate staff about opportunities available and constraints imposed by the outside world." (Cargill \& Webb, 1988; 60) They must appear confident and be reliable sources of information and advice. They interpret organizational situations. (Cargill \& Webb, $1988 ; 62$ ) They need to use reliable judgment and have a genuine concern for staff. "Consideration for individual needs, however, cannot impair the striving for the achievement of overall organizational goals or obscure present and future organizational goals. Leadership implies responsibility for one's actions." (Cargill \& Webb, 1988; 64)

Library leaders must inspire trust in the future of the organization and create a sense of cohesion. (Cargill \& Webb, 1988; 69) They need to be able to integrate people with different backgrounds into the organization by valuing their diversity and encouraging different approaches to problem solving. They work to develop each person's abilities. (Cargill \& Webb, 1988; 73) Underlying problems must be identified and resolved with mutual trust and respect. Directors must convince employees to find long-term solutions acceptable to all rather than short-term gain. (Cargill \& Webb, 1988; 73) They effectively delegate, think on their feet, and can anticipate the consequences of their decisions. (Cargill \& Webb, 1988; 79)

Disciplinary actions are an important responsibility. Expectations must be communicated clearly; "the employee who is either ignorant of expectations or is unwilling to change is creating the need for intervention. Employees need to accept responsibilities for their actions just as the manager needs to act on his or her responsibility to address problems." (Cargill \& Webb, 1988; 80) Staff training should be directed toward understanding and dealing with moving targets; many changes create unforeseen consequences and readjustments are necessary in goals and daily activities. (Cargill \& Webb, 1988; 90) 


\section{Management Styles}

Decision styles of directors vary by type of institution, as assessed using the "Decision Style Inventory." Most directors in comprehensive and baccalaureate institutions employ the behavioral decision style, which implies a low tolerance for ambiguity and an orientation toward people and social concerns. Directors in doctoral institutions prefer the conceptual decision style. This indicates a high tolerance for ambiguity and also an orientation toward people and social concerns. These directors are future-oriented thinkers who have a system perspective. (Mech, 1993; 379-83) Age is a factor in decision style used: those who have fewer years of experience tend to use the behavioral style more than those who have more administrative experience. More directors at private institutions use the behavioral style than those at public institutions

Lawson and Dorrell surveyed librarians at the Missouri state academic libraries. In general, the librarians did not think their directors practiced the management style they professed to practice. Staff did not always participate in decision-making. Directors did stand by difficult decisions, encourage staff to achieve their potential, and support professional development. Staff perceived themse'ves to be more loyal to the directors than the directors were to them. (Lawson \& Dorrell, 1992; 191)

Faerman's conceptual map of organizational and managerial leadership performance shows the relationship between organizational performance and managerial styles and behaviors. She examines preferences in leadership style and their effect on dealing with organizational change. She uses the competing values framework because libraries are organizations that have conflicting demands. She discusses user-centered organizations in terms of the rational goal model, the internal process model, and the human relations model. (Faerman, 1993)

A 1994 study showed that research university library directors considered themselves to have transformational leadership behaviors at a significantly higher level than their subordinates. Directors thought they could encourage greater effort from their staff and that they were more effective than their subordinates did. Male directors exhibited higher levels of non-leadership behavior than female directors. Female directors exhibited higher levels of transformational leadership behaviors, were perceived to be more effective, and were more satisfied than male directors. Directors with twenty years or less of experience used inspirational leadership more frequently and were perceived to be more satisfied than those who had more than twenty years of experience. (Suwannarat, 1994; 1-2)

A later study of transformational and transactional characteristics of library directors suggested that perceptions of leadership behavior are associated with perceptions of satisfaction with the leader, effectiveness of the leader, and amount of extra effort by followers. Transformational leadership had a greater effect on leadership outcomes and dimensions of organizational effectiveness than did transactional leadership. (Albritton, 1998; 78) It is "a measurable construct of identifiable behaviors such as the articulation of transcendent goals, demonstration of strong self-confidence and confidence in others, setting a personal example for followers, showing high expectations for followers' performance, and the ability to communicate one's faith in one's goals. Therefore, what is needed are training and education that promote selfunderstanding, awareness, and appreciation of the range of potential leadership behaviors used by effective transformational and transactional leaders." (Albritton, 1998; 80)

\section{Conclusion}

Although some research has been done on identifying library leadership potential, career development, characteristics and management styles of academic library directors, and their roles and responsibilities, it is clear that many aspects have not been addressed and that a comprehensive body of cohesive, evidence-based research is needed. There is a dearth of published studies or dissertations that relate leadership to effectiveness of library directors, their organizations, or outcomes. Although "character" is a current topic of discussion and research in the business and education leadership literature, it has not been related to education library leadership. Transformational versus transactional leadership have begun to be addressed, but other models have not. Within the framework of education libraries, the effects of different leadership styles on employee productivity and job satisfaction have not been studied; nor has it been determined which leadership styles and characteristics are most effective in which environments. Professio nal networking, social skills that are important for development and fundraising, relationships with university administrators, aspects of influence, and the effectiveness of different internal organizational models are areas that 
need to be explored. To have data in these areas, particularly as they relate to education libraries, would inform professional development programs, mentoring initiatives, and would provide university administrators with conclusive information when making hiring decisions.

\section{References}

Adamany, D. W. (1985). Research libraries from a presidential perspective. In P. SpyersDuran \& T. W. Mann (Ed s.), Issues in academic librarianship: Views and case studies for the 1980's and 1990's (pp. 5-20). Westport, CT: Green wood Press.

Albritton, R. L. (1998). A new paradig $m$ of leader effectiveness for academic libraries: An empirical study of the Bass (1985) Model of Transformational Leadership. In T. F. Mech \& G. B. McCabe (Eds.), Leadership and academic librarians (pp. 66-84). Westport, CT: Greenwood Press.

Almanac. (2003). The Chronicle of Higher Education, $L(1)$.

Anderson, D. J. (1985). Comparative career profiles of academic librarians: Are leaders different? Journal of Academic Librarianship, 10(6), 326-332.

Battin, P. (1998). Leadership in a transformational age. In B. L. Hawkins \& P. Battin (Eds.), The mirage of continuity: Reconfiguring academic information resources for the 21st century (pp. 271-277). Washington, DC: Council on Library and Information Resources Association of American Universities.

Buttlar, L. J., \& Garcha, R. (1992). Organizational structuring in academic libraries. Journal of Library Administration, 17(3), 1-21.

Cargill, J., \& Webb, G. M. (1988). Managing libraries in transition. Phoenix: Oryx Press.

Clemmer, J. G. (1997). The liberal arts college library director and the collegiate myth. Journal of Library Administration, 24(3), 73-88.

Cottam, K. M. (1994). Directors of large libraries: Roles, functions, and activities. [Electronic version]. Library Trends, 43(1), 15+.

Deekle, P. V., \& De Klerk, A. (1992). Perceptions of library leadership in a time of change. Journal of Library Administration, 17(1), 55-75.

Dilevko, J., \& Gottlieb, L. (2002). Making a difference in their own way: The role of library directors and non-directorial staff at tribal college libraries. Journal of Academic Librarianship, 28(5), 306-318.

Euster, J. R. (1984). Leaders and managers: literature review, synthesis, and a new conceptual framework. Journal of Library Administration, 5(1), 45-61.

Euster, J. R. (1986). The activities and effectiveness of the academic library director in the environmental context. Unpublished $\mathrm{PhD}$, University of California, Berkeley.

Euster, J. R. (1987). The academic library director: Management activities and effectiveness. New York: Greenwood Press.

Euster, J. R. (1989). The qualities of leadership. In A. Gertzog (Ed.), Leadership in the library/information profession (pp. 4-17). Jefferson, NC: McFarland.

Evans, J. D. (1997). Power use behaviors of library administrators: Relationships among administrators' preferred social power use, readiness to empower and administrators' characteristics. Unpublished PhD, Georgia State University.

Faerman, S. R. (1993). Organizational change and leadership styles. Journal of Library Administration, 19(3-4), 55-79.

Ferguson, C., \& Metz, T. (2003). Fin ding the third space: On leadership issues related to the integration of library and computing. In C. E. Regenstein \& B. I. Dewey (Eds.), Leadership, higher education, and the information age (pp. 95-112). New York: NealSchuman Publishers, Inc.

Fisher, W. (1997). The question of gender in library management. Library Administration \& Management, 11(4), 231-236.

Freedman, J. (1984). Empowering librarians: A study of the effects of the women's movement on the careers, work modes, and leadership styles of feminist librarians. Unpublished EdD, Boston University, Boston, MA.

Gertzog, A. (1989a). An investigation into the relationship between the structure of leadership and the social structure of the library profession. Unpublished PhD, Rutgers The State University of New Jersey, New Brunswick, NJ.

Gertzog, A. (1989b). Perceptions of leadership. In A. Gertzog (Ed.). Leadership in the library/information profession (pp. 18-34). Jefferson, NC: McFarland and Company, Inc.

Hall, J. A. (1984). The relationship between innovative or change agent characteristics of academic librarians and the existence of 
change in selected academic libraries in the southeastern United States. Unpublished PhD, University of Michigan.

Hammond, E. D. (2003). Rising to the top: The peculiar leadership challenges for the successful internal candidate. In C. E. Regenstein \& B. I. Dewey (Eds.). Leadership, higher education, and the information age (pp. 181-189). New York: Neal-Schuman.

Hatcher, K. A. (1997). Succession paths for academic library directors. Journal of Library Administration, 24(3), 31-46.

Hernon, P., Powell, R. R., \& Young, A. P. (2001). University library directors in the Association of Research Libraries: The next generation, part one. [Electronic version]. College \& Research Libraries, 62(2), 116-145.

Hernon, P., Powell, R. R., \& Young, A. P. (2002). University library directors in the Association of Research Libraries: The next generation, part two. [Electronic version]. College \& Research Libraries, 63(1), 73-90.

Holmes, R. C. (1983). The academic library director's perceived power and its correlates. Unpublished PhD, University of Minnesota.

Hyatt, J. A., \& Santiago, A. A. (1987). University libraries in transition. Washington, DC: National Association of College and University Business Officers.

lannuzzi, P. (1992). Leadership development and organizational maturity. Journal of Library Administration, 17, 19-36.

Jurow, S. (1990). Preparing for library leadership. Journal of Library Administration, 12(2), 66-71.

Kazlauskas, D. W. (1993). Leadership practices and employee job satisfaction in the academic libraries of the state university system of Florida. Unpublished EdD, University of Florida.

Kirkland, J. (1997). The missing women library directors: Deprivation versus mentoring. College \& Research Libraries, 58(4), 376-384.

Lawson, V. L., \& Dorrell, L. (1992). Library directors: Leadership and staff loyalty. Library Administration \& Management, 6, 187-91.

Martin, R. R. (1997). Recruiting a library leader for the 21 st century. In F. D'Andrai a (Ed.). The academic library director: Reflections on a position in transition (pp. 47-58). New York: Haworth.

Matthews, C. J. (2002). Becoming a chief librarian: An analysis of transition stages in academic library leadership. [Electronic version]. Library Trends, 50(4), 578-602.
McCracken, P. H. (2000). The presence of the doctorate among small college library directors. College \& Research Libraries, 61(5), 400-408.

McElrath, E. (2002). Challenges that academic library directors are experiencing as perceived by them and their supervisors [Electronic version]. College \& Research Libraries, 63(4), 304-321.

McNeer, E. J. (1988). The mentoring influence in the careers of women ARL directors. Journal of Library Administration, 9(2), 23-33.

Mech, T. F. (1990). Academic library directors: A managerial role profile. College \& Research Libraries, 51 (5), 415-428.

Mech, T. F. (1993). The managerial decision styles of academic library directors. College \& Research Libraries, 54(5), 375-386.

Mobley, E. R. (1989). Woman and minorities as leaders. In A. Gertzog (Ed.). Leadership in the library/information profession (pp. 4350). Jefferson, NC: McFarland.

Moore, M. M. (1981). First career, second career, and alternative career academic librarians: A study in personality and leadership differentials as related to managerial talent. Unpublished Ph.D., Florida State University.

Myers, M. J., \& Kaufman, P. T. (1991). ARL directors: Two decades of changes. College \& Research Libraries, 52(3), 241-254.

Renaud, R., \& Murray, A. (2003). Organizing for leadership: How university libraries can meet the leadership challenge in higher education. In C. E. Regenstein \& B. I. Dewey (Eds.), Leadership, higher education, and the information age (pp. 163180). New York: Neal-Schuman.

Riggs, D. E. (1998). Visionary leadership. In T. F. Mech \& G. B. McCabe (Eds.), Leadership and academic librarians (pp. 55-65). Westport, CT: Greenwood.

Riggs, D. E., \& Sabine, G. A. (1988). Libraries in the 90's: What the leaders expect. Phoenix: Oryx.

Rooks, D. C. (1994). Terms for academic library directors. [Electronic version]. Library Trends, 43(1), 47-61.

Sheldon, B. E. (1992). Library leaders: Attributes compared to corporate leaders. Library Trends, 40, 391-401.

Suwannarat, P. (1994). Library leadership in research university libraries. Unpublished Ed.D., Vanderbilt University, Nashville, TN.

Talbot, R. J. (1982). Financing the academic library. In T. J. Galvin \& B. P. Lynch (Eds.). 
Priorities for academic libraries (Vol. 39, pp. 35-44). San Francisco: Jossey-Bass.

Travica, B. (1999). Organizational aspects of the virtual library: A survey of academic libraries. Library \& Information Science Research, 21(2), 173-203.

Wedgeworth, R. (1989). Nurturing leadership: A personal view. In A. Gertzog (Ed.). Leadership in the library/information profession (pp. 35-42). Jefferson, NC: McFarland.

Wiegand, W. A. (1983). Leaders in American academic librarianship, 1925-1975. Pittsburgh, PA: Beta Phi Mu.

Williams, D. E. (1998). The library director as a campus leader. In T. F. M ech \& G. B. McCabe (Eds.), Leadership and academic librarians (pp. 39-54). Westport, CT: Greenwood Press.
Williams, J. F., \& Winston, M. D. (2003). Leadership competencies and the importance of research methods and statistical analysis in decision making and research and publication: A study of citation patterns. Library \& Information Science Research, 25, 387402.

Winston, M. D., \& Dunkley, L. (2002). Leadership competencies for academic librarians: the importance of development and fundraising. [Electronic version]. Coliege \& Research Libraries, 63(2), 171-82.

Sharon Gray Weiner is Director, Peabody Library, Vanderbilt University. Email:

s.weiner@vanderbilt.edu

Figure 1. Study characteristics of publications included in review.

\begin{tabular}{|c|c|c|c|c|}
\hline Authors & Method/Model & Study Date & \# Respondents & Institution Type \\
\hline$\overline{\text { Albritton (1998) }}$ & Survey & N/A & 23 & ACRL, ARL Libraries \\
\hline Anderson (1984) & $\begin{array}{l}\text { Comparison by random } \\
\text { sample }\end{array}$ & N/A & 229 & $\begin{array}{l}\text { UCLA Senior Fellows } \\
\text { \& match group }\end{array}$ \\
\hline Buttlar (1992) & Survey & N/A & 93 & state college/universities \\
\hline Clemmer (1997) & Telephone interviews & N/A & 9 & $\begin{array}{l}\text { Directors of Oberlin Group } \\
\text { libraries }\end{array}$ \\
\hline Cottam (1994) & Survey & $\mathrm{N} / \mathrm{A}$ & 30 & $\begin{array}{l}\text { Directors of large libraries } \\
\text { or library systems }\end{array}$ \\
\hline Deekle, deKlerk ( & (1992) Survey & 1991 & 250 & $\begin{array}{l}\text { Small/medium private col- } \\
\text { leges/ universities }\end{array}$ \\
\hline Dilevko, Gottlieb & Survey & 2001 & 33 & Tribal college library staff \\
\hline Euster (1986) & Survey & N/A & 42 & $A R L$ or $A C R L$ lib. directors \\
\hline Euster (1989) & Two Environment Model & & & \\
\hline Evans (1997) & Correlational, Surveys & N/A & 75 & $\begin{array}{l}\text { Masters I/II public colleges } \\
\text { east coast, South }\end{array}$ \\
\hline Fisher (1997) & Record review & N/A & N/A & All library directors \\
\hline Freedman (1984) & Interview & N/A & 20 & Feminist librarians \\
\hline Gertzog (1989) & Survey 1 & 1987 & 313 & $\begin{array}{l}\text { Library administrators } \\
\text { leducators }\end{array}$ \\
\hline Gertzog (1989) & Survey II & 1987 & 385 & $\begin{array}{l}\text { Library administrators } \\
\text { /educators }\end{array}$ \\
\hline Hall (1984) & Survey & N/A & 222 & $\begin{array}{l}\text { Assn. of Southeastern } \\
\text { Research Libraries }\end{array}$ \\
\hline Hatcher (1997) & Survey & $\mathrm{N} / \mathrm{A}$ & 21 & $\begin{array}{l}\text { Council on State Univer- } \\
\text { sity Libraries }\end{array}$ \\
\hline Hernon, et al (20C & $\begin{array}{l}\text { 01) Content analysis, } \\
\text { interviews }\end{array}$ & $1999-2000$ & 15 & ARL directors \\
\hline Hernon, et al (20C & 02) Delphi study & $1 / 2001$ & 20 & ARL directors \\
\hline Hernon, et al (20C & 02) Delphi study & $4 / 2001$ & 29 & $\begin{array}{l}\text { ARL asst., assoc., deputy } \\
\text { directors }\end{array}$ \\
\hline Holmes (1983) & Survey & 1981 & 583 & $\begin{array}{l}\text { Carnegie } 1 \& 2 \text { liberal arts } \\
\& \text { comp. colleges/univ. }\end{array}$ \\
\hline Hyatt, Santiago ( & 1987) Case study & N/A & 4 & $\begin{array}{l}\text { Princeton, U. IL, NYU, U. } \\
\text { Georgia }\end{array}$ \\
\hline
\end{tabular}




\begin{tabular}{|c|c|c|c|c|}
\hline \multicolumn{2}{|c|}{ Kazlauskas (1993) Surveys (3) } & N/A & 164 & $\begin{array}{l}\text { Florida State University } \\
\text { system librarians }\end{array}$ \\
\hline Kirkland (1997) & Survey I & N/A & 50 & Women librarians \\
\hline Kirkland (1997) & Survey II & N/A & 61 & $\begin{array}{l}\text { Women academic library } \\
\text { directors }\end{array}$ \\
\hline Matthews (2002) & $\begin{array}{l}\text { Nicholson \& West } \\
\text { Transition Cycles Model }\end{array}$ & N/A & N/A & Academic libraries \\
\hline McCracken (2000) & ) Survey & N/A & 80 & Baccalaureate I colleges \\
\hline McElrath (2002) & Content analysis; survey & 1999 & 72 & $\begin{array}{l}\text { Masters I/II public univer- } \\
\text { sities in south }\end{array}$ \\
\hline McNeer (1988) & Survey & 1985 & 16 & Female ARL directors \\
\hline Mech (1990) & Survey & 1989 & 354 & $\begin{array}{l}\text { Midwest academic library } \\
\text { directors }\end{array}$ \\
\hline Mech (1993) & $\begin{array}{l}\text { Survey \& Decision Style } \\
\text { Inventory }\end{array}$ & 1990 & 370 & Academic library directors \\
\hline Mitchell (1989) & $\begin{array}{l}\text { Fiedler's Contingency } \\
\text { Model of Leadership }\end{array}$ & N/A & 209 & $\begin{array}{l}\text { Academic library depart- } \\
\text { ment heads }\end{array}$ \\
\hline Moore (1981) & Comparison study & N/A & & \\
\hline $\begin{array}{l}\text { Myers, } \\
\text { Kaufman (1991) }\end{array}$ & Record review & 1989 & 1,798 & ARL directors \\
\hline Sheldon (1992) & Interviews & N/A & 61 & $\begin{array}{l}\text { Directors, deans, state } \\
\text { libns., org. exec. directors }\end{array}$ \\
\hline Suwannarat (1994 & 4) Survey & $\mathrm{N} / \mathrm{A}$ & 173 & ARL dir. \& sub ordinates \\
\hline Travica (1999) & Survey & N/A & 205 & Academic library directors \\
\hline $\begin{array}{l}\text { Williams, } \\
\text { Winston (2003) }\end{array}$ & Bibliometric analysis & N/A & N/A & N/A \\
\hline $\begin{array}{l}\text { Winston, } \\
\text { Dunkley (2002) }\end{array}$ & Content analysis & N/A & N/A & Academic libraries \\
\hline
\end{tabular}

